\title{
POSTMORTEM EXAMINATIONS OF DEATHS IN POLICE CUSTODY- CHALLENGES FACED BY FORENSIC PATHOLOGISTS IN SRI LANKA IN RELATION TO CAUSAL FACTORS
}

\author{
P.A.S. Edirisinghe \\ Senior Lecturer, Department of Forensic Medicine, Faculty of Medicine, University of Kelaniya, \\ Sri Lanka
}

\section{INTRODUCTION}

Postmortem examination of a death in police custody requires prior organization and planning. Such a post mortem examination is not only aimed at finding the cause of death, but also aimed at addressing other medico-legal issues related to arrest/custody. Although the detained individuals are ñsuspectedò to have broken the existing law of the land, all investigators have a legal and an ethical duty, to safeguard and ensure their human rights. Some believe this dual responsibility of the investigators, especially, of the police makes any death in police custody potentially controversial. ${ }^{1}$

This paper attempts to highlight some challenges faced by forensic pathologists in Sri Lanka in dealing with postmortem examinations concerning deaths in custody, using two cases.

\section{$\underline{\text { Case - } 1}$}

A 71-year-old male, who actively engaged in cultivation, collapsed while being arrested by the police for possession of illicit liquor. He was pronounced dead on admission to hospital. The subsequent postmortem examination revealed that the coronary arteries were $60-80 \%$ occluded with subendocardial and myocardial fibrosis (Figure 12). Minor injuries (abrasions and contusions) found in the forearms and buttocks (Figure 3) were diagnosed as injuries that could have resulted from an encounter with the police, but they were not sufficient to cause the death. A retrospective scene visit examination was conducted to find the extent of exertion prior to death.

The final medical opinion concerning the cause of death of this victim was that ñnjuries, exertions, and excitement during the arrest had created an acute coronary insufficiency which caused the deathò. The police officers were subsequently charged for causing ñgrievous hurtò.

\section{$\underline{\text { Case }-2}$}

A 25- year-old soldier who was arrested one night by the police, on suspicion of robbery, was found dead in the police cell hanging with the belt of his trousers, the following day morning. The mother of the victim alleged that the victim was tortured by the police prior to death. Scene visit examination revealed that, it was a complete hanging, and the point of suspension could have been reached by the individual (Figure 4). The autopsy revealed that there were no injuries except the ligature mark, in the upper neck which was directing upwards (Figure $5 \& 6$ ). The cause of death was provided as ñigature suspension of the neckò. The opinion on the analysis of the scene visit findings was that the death was compatible with self-suspension.

Although a second postmortem examination was carried out after 1 year later, there was no change made to the cause of death or the circumstance of the death.

\section{DISCUSSION}

Although the statistics of the causes of deaths in police custody varies from country to country and from region to region [1-4], they can be basically categorized into three types of deaths, according to the causal factors.

(a) deceased on actions

(b) deceased on medical condition, and

(c) another personôs action that may have been associated.

A study conducted in the UK states that $63 \%$ of police custody deaths during 1990-1996 were due to the deceased on actions where deliberate self harm from hanging was the number one cause. ${ }^{1,2}$

Although there are no studies from Sri Lanka, categorizing the deaths in custody according to their causal factors, forensic pathologists frequently encounter custodial deaths in routine autopsy examinations. The opinion expressed by a pathologist in the investigation of police 
custodial deaths plays a crucial role in finding the culpability especially those related to torture. In Sri Lanka óWijedasa Liyanarachchiô murder trial in 1990 was an example. ${ }^{5}$

Although the cause of death was natural in case no: 1 , described above, aggravation of the natural disease was due to events related to the arrest. Therefore the contribution of the arrest to the causal factor has to be accounted for. The stress and adrenergic reactions leading to death in cardiac compensated individuals are well documented in medical literature. Such example was an unexpected increase of individuals suffering from sudden cardiac deaths in Northridge (Los Angeles) earthquake in 1994 which has been attributed to emotional stress related adrenergic stimulation. ${ }^{6}$

Deliberate self harm is a well known phenomenon in offenders in jails or police custody. 7 Suicide by hanging is the commonest. ${ }^{1,7,8}$ The second case study highlights the issue of difficulty in accepting this common phenomenon although statistics throughout the world show similar trends. Although comprehensive postmortem reports and scene visit reports were given to courts, an exhumation and $2^{\text {nd }}$ examination resulted in the second case where neither the cause of death nor the number of injuries changed highlighting the issue of unnecessary expenses incurred to the government for mere satisfaction of the family.

Although the challenges in causal factors in custodial deaths are there for the pathologist, the logistic issues are the main concerns. Lack of facilities such as equipments, radiology, photography, histology (special stains), biochemistry, microbiology and DNA are some hindrance in Sri Lanka that can be named in forensic investigations. The other factor is the socio-cultural practices of Sri Lankans related to death where the relatives demand for quick postmortems/release the bodies without postmortem examinations to organize the funeral.

\section{ACKNOWLEDGEMENT}

Dr.Ananda Samarasekera, Consultant JMO, Teaching Hospital Ragama, who supervised the investigation of these two cases.

\section{REFERENCE}

1. Leigh A, Johnson G, Ingram A. Deaths in Police Custody: Learning the lessons, Eds Laycock G. Police Research Series paper 26, Home Office London UK, 1998

2. Norfolk GA, Death in police custody during 1994: a retrospective analysis, J of Clin Foren Med, 1998; 5: 49-54

3. Wobeser WL, Datema J, Bechard B, Ford P, Causes of death among people in custody in Ontario, 1990-1999. CMAJ, 2002; 167:10-18

4. Curnow J and Joudo J 2009. Deaths in custody in Australia: National Deaths in Custody Program 2007. Monitoring reports series, no. 03. Canberra: Australian Institute of Criminology. http://www.aic.gov.au/en/statistics/deathscustody/ police.aspx Web site contacted on 2.10.2009

5. Abdication of Responsibility ï The Commonwealth and Human Rights, A human Rights watch report 1991http://www.hrw.org/reports/pdfs/g/general/general 2910.pdf web site contacted on 2.10.2009

6. Leor $\mathrm{J}$ et al: Sudden cardiac death triggered by an earthquake. N Engl J Med, 1996;334:413-17.

7. Lohner J, Konrad N. Deliberate self-harm and suicide attempt in custody: Distinguishing features in male inmates' self-injurious behavior International Journal of Law and Psychiatry. 2006;29: 370-385.

8. Inch H, Rowlands P, Soliman Deliberate self-harm in a young offenders' institution A. Journal of Forensic Psychiatry \& Psychology.1995;6: 161 ï 171 
$\underline{\text { Case } 1}$
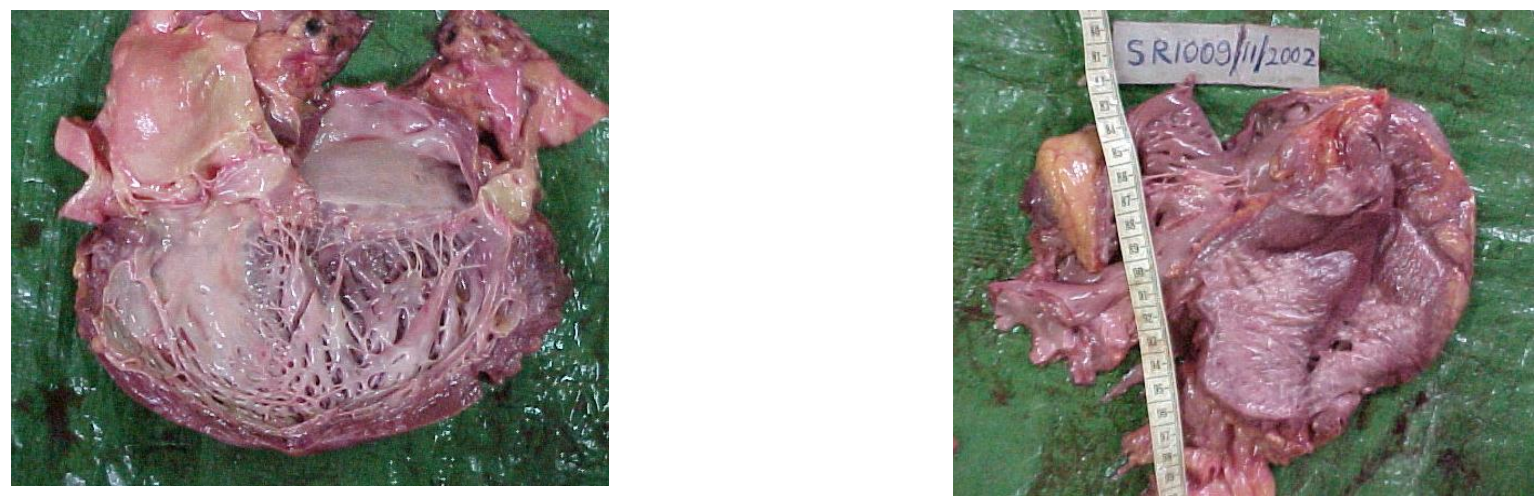

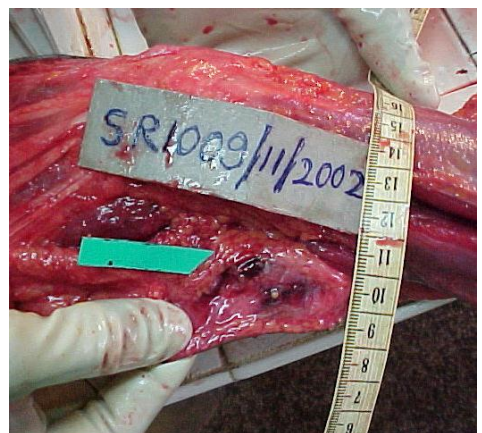

Figure 1: Sub-endocardial fibrosis

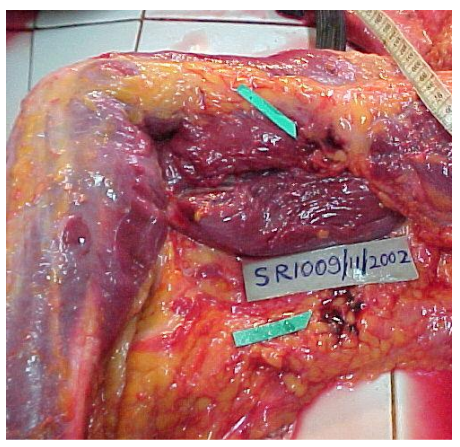

Figure 2: Myocardial fibrosis

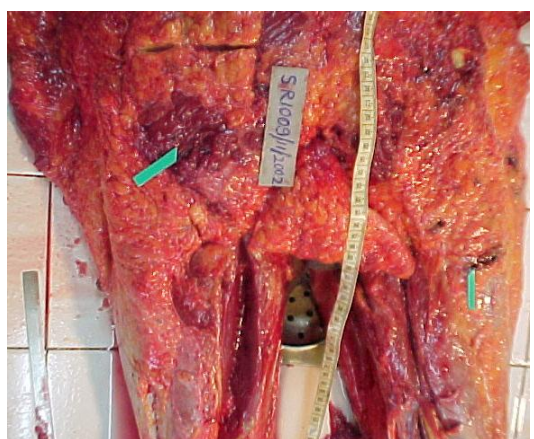

Figure 3: minor injuries (contusions)

Case 2

Figure 4: Scene visit photographs showing the accessibility and the suspension.
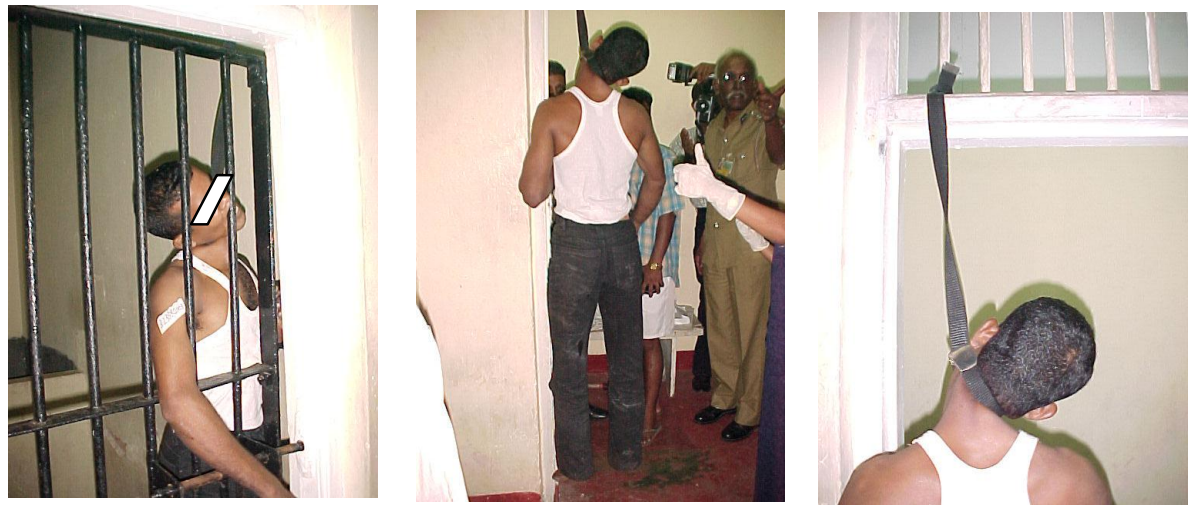

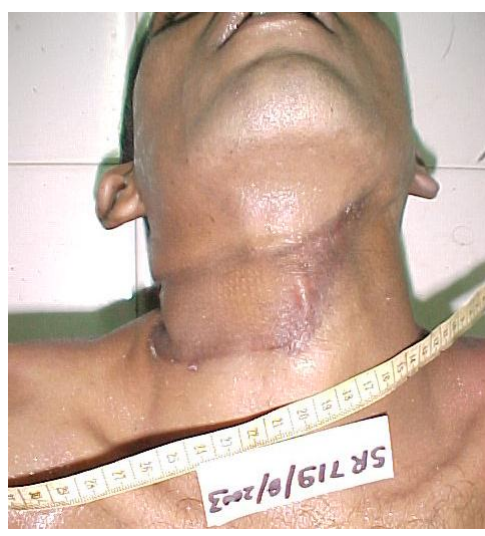

Figure 5: Imprint abrasions
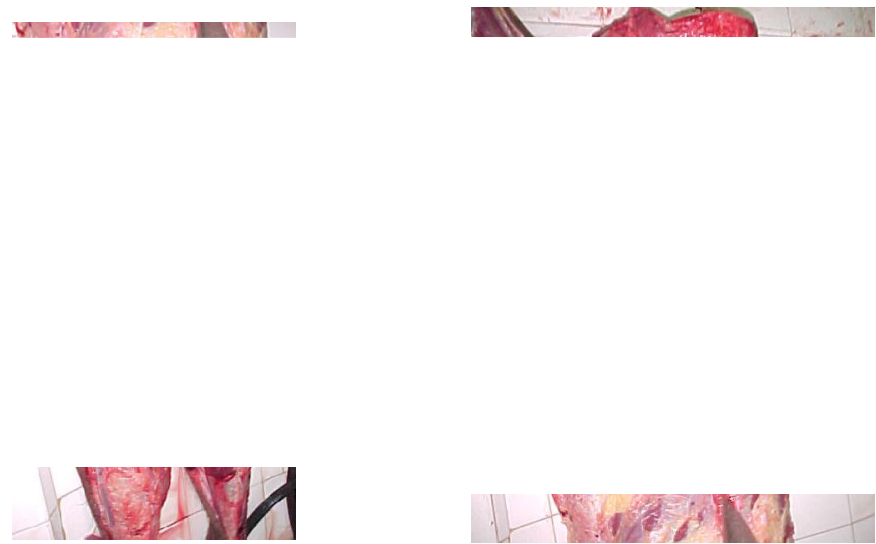

Figure 6\& 7: Absence of injuries 